ALBERTI, Arnaldo, ed. La Romania. Milan and Bucharest: Edizioni del Calendario and Istituto di studi storici politici e sociali, 1976. 232 pp. Photographs.

ANDREYEV, Olga Chernov. Cold Spring in Russia. Foreword by Arthur Miller. Trans. by Michael Carlisle. Ann Arbor: Ardis, 1978. x, 283 pp. +6 pp. photographs. $\$ 13.95$, cloth. $\$ 6.95$, paper.

BACHMANN, Harald. Joseph Maria Baernreither (1845-1925): Der Werdegang eines altösterreichischen Ministers und Sozialpolitikers. Neustadt/Aisch: Verlag $\mathrm{Ph}$. C. W. Schmidt, 1977. 178 pp. DM 38, paper.

BACKER, John H. The Decision to Divide Germany: American Foreign Policy in Transition. Durham, N.C.: Duke Univ. Press, 1978. x, 212 pp. $\$ 9.95$.

BARAC, Antun. A History of Yugoslav Literature. Trans. by Petar Mijušković. Ann Arbor: Michigan Slavic Publications, Univ. of Michigan, n.d. 266 pp.

BELY, Andrei. Petersburg. Trans., annotated, and with an intro. by Robert $A$. Maguire and John E. Malmstad. Bloomington and London: Indiana Univ. Press, 1978. xxviii, 356 pp. $\$ 17.50$.

BERNER, Wolfgang, et al., eds. The Soviet Union 1975-76: Domestic Policy, Economics, Foreign Policy. Trans. by Hannes Adomeit and Roger Clarke. New York: Holmes \& Meier, 1977. xiv, 308 pp. \$18.50.

BERNER, Wolfgang, et al., eds. Sowjetunion 1976/77: Innenpolitik, Wirtschaft, Aussenpolitik. Analyse und Bilanz. Munich and Vienna: Carl Hanser Verlag, 1977. 299 pp. Paper.

BERZA, M., and E. Stănescu, eds. Actes du XIVe Congrès International des Etudes Byzantines: Bucarest, 6-12 septembre, 1971, vol. 2. Bucharest: Editura Academiei Republicii Socialiste România, 1975. 656 pp. +108 pp. plates. Lei 57.

BERZA, M., and E. Stănescu, eds. Actes du XIVe Congrès International des Etudes Byzantines: Bucarest, 6-12 septembre, 1971, vol. 3. Bucharest: Editura Academiei Republicii Socialiste România, 1976. 738 pp. + 122 pp. plates. Lei 57.

BISZTRAY, George. Marxist Models of Literary Realism. New York: Columbia Univ. Press, 1978. viii, 247 pp. $\$ 13.00$.

Leonid I. Brezhnev: Pages From His Life. Written under the auspices of the Academy of Sciences of the USSR. Foreword by Leonid I. Brezhnev. New York: Simon and Schuster, 1978. 320 pp. +40 pp. plates. $\$ 11.95$.

BRISTOW, Eugene K., ed. and trans. Anton Chekhov's Plays: The Sea Gull, Uncle Vanya, The Three Sisters, The Cherry Orchard. Backgrounds, Criticism. A Norton Critical Edition. New York: W. W. Norton, 1977. xxxii, 412 pp. Paper.

Budapest története a Márciusi forradalomtól az őszirózsás forradalomig. Ed. by György Spira and Károly Vörös. Budapest: Akadémiai Kiadó, 1978. 809 pp. Illus. Maps. $210 \mathrm{Ft}$

CATANOY, Nicholas, ed. Modern Romanian Poetry. Foreword by Irving Layton. Oakville, Ottawa: Mosaic Press/Valley Editions, 1977. 142 pp. $\$ 9.50$, cloth. $\$ 4.50$, paper.

CAUTE, David. The Great Fear: The AntiCommunist Purge Under Truman and Eisenhower. New York: Simon and Schuster, 1978. 697 pp. $\$ 14.95$.

CEAUSESCU, Nicolae. Scritti scelti (1976). Milan: Edizioni del Calendario, 1977. 366 pp. +16 pp. plates.

CHRISTA, Boris. The Poetic World of Andrey Bely. Amsterdam: Verlag Adolf M. Hakkert, 1978. viii, 150 pp. Sw.Fr. 36, paper.

Classe operaia e unità d'azione in Romania: Sessione scientifica organizzata in occasione del trentesimo anniversario della fondazione del Fronte unico operaio in Romania, Bucarest, 25-27 aprile 1974. Rome: Editori Riuniti, in collaborazione con l'Istituto di studi storici sociali e politici di Bucarest, 1976. 271 pp. Lire 6.000.

COLLIGNON, Jean-Guy. Les Juristes en Union Soviétique. Paris: Editions du Centre National de la Recherche Scientifique (15, quai Anatole-France), 1977. x, 555 pp. Paper.

COMENIUS, John Amos. The Labyrinth of the World and the Paradise of the Heart. New trans. by Matthew Spinka. Ann Arbor: Dept. of Slavic Langs. \& Lits., Univ. of Michigan, in collaboration with the Czechoslovak Society of Arts and Sciences in America, 1972. xvi, 148 pp. +55 pp. of the Facsimile of the Final Version of The Labyrinth (Amsterdam, 1663). Paper.

CRONIN, Vincent. Catherine: Empress of All the Russias. New York: William Mor- 
row, 1978. 349 pp. +30 pp. photographs. $\$ 12.95$.

DAVIES, R. W., ed., with the assistance of Denis J. B. Shaw. The Soviet Union. London: George Allen \& Unwin, 1978. 191 pp. Illus. $\$ 14.75$, cloth. $\$ 7.50$, paper.

DEBRECZENY, Paul, and Thomas Eekman, eds. Chekhov's Art of Writing: A Collection of Critical Essays. Foreword by Ronald Hingley. Columbus, Ohio: Slavica, 1977. iv, 199 pp. \$8.95, paper.

DENIS-JONES, Harold, Peter Sheldon, and Richard Moore, eds. Fodor's Yugoslavia 1978-79. New York: David McKay, 1978. 328 pp. + 12 pp. plates and 8 pp. maps. $\$ 10.95$.

DUNN, Dennis J., ed. Religion and Modernization in the Soviet Union. Boulder, Colo.: Westview Press, 1977. x, 414 pp. Illus. $\$ 21.75$.

DUNN, Stephen B., and Ethel Dunn. Kulturwandel im sowjetischen Dorf. Berlin: Duncker \& Humblot in Kommission, 1977. 200 pp. Paper.

ERARD, A. Z., and G. M. Zygier, comps. La Pologne: Une société en dissidence. Preface by Alexander Smolar. Paris: François Maspero (1, place Paul-Painlevé), 1978. 195 pp. Paper.

FISHER, Raymond H. Bering's Voyages: Whither and Why. Seattle and London: Univ. of Washington Press, 1977. xiv, 217 pp. Maps. $\$ 17.95$.

FLEISCHHAUER, Ingeborg. Philosophische Aufklärung in Russland: Rationaler Impuls und mystischer Umbruch: N. N. Strachov. Rome: Pont. Institutum Orientalium Studiorum, 1977. 270 pp. Paper.

FODOR, Eugene, et al., eds. Fodor's Czechoslovakia 1977-78. New York: David McKay, 1977. xii, 336 pp. $\$ 12.95$.

FORSYTH, James. Listening to the Wind: An Introduction to Alexander Blok. Oxford: Willem A. Meeuws, 1977. vi, $138 \mathrm{pp}$. $\$ 4.50$, paper. (Available from Holdan Books, 15 N. Parade Ave., Oxford OX2 6LX, England.)

GALLIE, W. B. Philosophers of Peace and War: Kant, Clausewitz, Marx, Engels and Tolstoy. New York and London: Cambridge Univ. Press, 1978. x, 147 pp. \$12.95.

GEYER, Dietrich. Der russische Imperialismus: Studien über den Zusammenhang von innerer und auswärtiger Politik 18601914. Göttingen: Vandenhoeck \& Ruprecht, 1977. 344 pp. DM 54, paper.

GREEN, William, and Gordon Swanborough. Soviet Air Force Fighters: Part One. World War II Fact Files. New
York: Arco Pub. Co., 1977. 68 pp. Illus. $\$ 4.95$, paper.

HARASOWSKA, Marta, and Orest O1hovych, eds. The International Sakharov Hearing. Baltimore and Toronto: Smoloskyp Publishers, 1977. 335 pp. $\$ 8.95$.

HEJZLAR, Zdenek. Reform Kommunismus: Zur Geschichte der Kommunistischen Partei der Tschechoslowakei. Cologne and Frankfurt: Europäische Verlagsanstalt, 1976. 479 pp. Paper.

HIGHAM, Robin, and Jacob W. Kipp, eds. Soviet Aviation and Air Power: A Historical View. Boulder, Colo.: Westview Press, 1977. London: Brassey's, 1978. xii, 328 pp. Illus. $\$ 25.00$.

HILL, Steven P. The N-Factor and Russian Prepositions: Their Development in Eleventh-Twentieth Century Texts. The Hague, Paris, and New York: Mouton, 1977. 365 pp. DM 98. Dist. by Walter De Gruyter, New York and Berlin.

HORCHLER, Gabriel Francis, comp. Hungarian Economic Reforms: A Selective, Partially Annotated Bibliography. New Brunswick, N.J.: The Hungarian Research Center, American Hungarian Foundation, 1977. x, 182 pp. $\$ 8.95$, cloth. $\$ 4.95$, paper.

Independenţa României: Documente, vol. 2, part 1: Corespondență diplomatică străină, 1853-1877 mai. Bucharest: Editura Academiei Republicii Socialiste România, 1977. Ixiv, 428 pp. Illus. Lei 34.

Independenţa României: Documente, vol. 2, part 2-a: Corespondenţă diplomatică străină, 1877 mai-1878 decembrie. Bucharest: Editura Academiei Republicii Socialiste România, 1977. liv, 381 pp. Illus. Lei 30 .

Independenţa României: Documente, vol. 3: Presă străină. Bucharest: Editura Academiei Republicii Socialiste România, 1977. liv, 338 pp. Illus. Lei 29.

IVINSKAYA, Olga. A Captive of Time. Trans. and with an intro. by Max Hayward. Garden City, N.Y.: Doubleday, 1978. xlii, 462 pp. +28 pp. photographs. $\$ 12.50$.

KALVODA, Josef. Czechoslovakia's Role in Soviet Strategy. Washington, D.C.: University Press of America, a division of R. F. Publishing, 1978. $x, 382$ pp. $\$ 8.75$, paper.

KERBLAY, Basile. La Société soviétique contemporaine. Paris: Armand Colin (103 bd. Saint-Michel, Paris 5e), 1977. 304 pl). Paper.

KI'TCH, Faith C. M. The Literary Style of Epifanij Premudryj, Pletenije Sloves. Munich: Verlag Otto Sagner, 1976. 298 pp. DM 34, paper. 
KNEI-PAZ, Baruch. The Social and Political Thought of Leon Trotsky. Oxford: Clarendon Press, 1978. xxii, 629 pp.

KOSTANICK, Huey Louis, ed. Population and Migration Trends in Eastern Europe. Boulder, Colo.: Westview Press, 1977, xiv, 247 pp. $\$ 17.50$.

KRAVCHENKO, Maria. Dostoevsky and the Psychologists. Amsterdam: Verlag Adolf M. Hakkert, 1978. viii, 177 pp. Sw. Fr. 40, paper.

KRUGER, Horst. Ostwest-Passagen: Reisebilder aus zwei Welten. Hamburg: Hoffmann und Campe, 1975. 304 pp. DM 24.

LAMMICH, Maria. Das deutsche Osteuropabild in der Zeit der Reichsgründung. Boppard am Rhein: Harald Boldt Verlag, 1978. viii, 298 pp. DM 74, paper.

LARGE, Brian. Martinu. New York: Holmes \& Meier, 1976, xiv, 198 pp. Plates. $\$ 19.50$.

I.AVIGNE, Marie, ed. Economie politique de la planification en système socialiste. Paris: Economica (49, rue Héricart), 1978. 328 pp. Paper.

LEGTERS, Lyman H., ed. The German Democratic Republic: A Developed Socialist Society. Boulder, Colo.: Westview Press, 1978. xiv, 285 pp. $\$ 20.00$.

LEONTIEF, Wassily, ed. Structure, System and Economic Policy: Proceedings of Section $\mathrm{F}$ of the British Association for the Advancement of Science held at the University of Lancaster, 1-8 September 1976. New York and London: Cambridge Univ. Press, 1977. xii, 223 pp. $\$ 18.95$.

LIBER, George, and Anna Mostovych, comps. Nonconformity and Dissent in the Ukrainian SSR, 1955-1975: An Annotated Bibliography. Cambridge, Mass.: Harvard Ukrainian Research Institute, 1978. xl, 245 pp. Paper.

LOUIS, Victor, and Jennifer Louis. The Complete Guide to the Soviet Union. New York: St. Martin's Press, 1976. ii, 369 pp. +24 pp. photographs. Maps. $\$ 7.95$, paper.

LUBOS, Arno. Schlesisches Schriftum der Romantik und Popularromantik. Munich: Wilhelm Fink Verlag, 1978. 195 pp. DM 32, paper.

McAULIFFE, Mary Sperling. Crisis on the Left: Cold War Politics and American Liberals, 1947-1954. Amherst: Univ. of Massachusetts Press, 1978. xii, 204 pp. $\$ 12.50$.

McCULLY, Newton A., Lieutenant Commander, U.S. Navy. The McCully Report: The Russo-Japanese War, 1904-05. Ed. by Richard A. von Doenhoff. Annapolis, Md.:
Naval Institute Press, 1977. xiv, 338 pp. Illus.

MAGOCSI, Paul Robert. The Shaping of a National Identity: Subcarpathian Rus', 1848-1948. Cambridge, Mass. and London: Harvard Univ. Press, 1978. xvi, 640 pp. Maps. \$25.00.

MARSHALL, Herbert. The Pictorial History of the Russian Theatre. Intro. by Harold Clurman. New York: Crown Publishers, 1977. xvi, 208 pp. Photographs. $\$ 14.95$.

MAXIMOV, Vladimir, gen. ed. Kontinent 3. Garden City, N.Y.: Anchor Press/Doubleday, 1978. xii, 225 pp. $\$ 3.95$, paper.

MEDVEDEV, P. N., and M. M. Bakhtin. The Formal Method in Literary Scholarship: A Critical Introduction to Sociological Poetics. Trans. by Albert J. Wehrle. Baltimore and London: The Johns Hopkins Univ. Press, 1978. xxvi, 191 pp.

MEISTER, Jürg. Soviet Warships of the Second World War. New York: Arco Pub. Co., 1977. vi, 348 pp. Illus. \$19.95.

MENZEL, Josef Joachim. Die schlesischen Lokationsurkunden des 13. Jahrhunderts: Studien zum Urkundenwesen, zur Siedlungs-, Reichts- und Wirtschaftsgeschichte einer ostdeutschen Landschaft im Mittelalter. Würzburg: Holzner Verlag, 1977. xxxvi, 482 pp. +8 pp. plates. DM 120.

METCALF, Michael F. Russia, England and Swedish Party Politics, 1762-1766: The Interplay between Great Power Diplomacy and Domestic Politics during Sweden's Age of Liberty. Stockholm and Totowa, N.J.: Almqvist \& Wiksell International and Rowman and Littlefield, 1977. x, 278 pp. $\$ 35.00$.

MILLER, R. F. External Factors in Yugoslav Political Development. Canberra: Dept. of Political Science, Research School of Social Sciences, Australian National University, 1977 . vi, 79 pp. $\$ 4.95$ plus postage, paper.

NAUMANN, Marina Turkevich. Blue Evenings in Berlin: Nabokov's Short Stories of the 1920s. New York: New York Univ. Press, 1978. xviii, 254 pp. $\$ 12.50$.

NEKRICH, Aleksandr M. The Punished Peoples: The Deportation and Fate of Soviet Minorities at the End of the Second World War. Trans. from the Russian by George Saunders. New York: W. W. Norton, 1978. xiv, 238 pp. $\$ 10.95$.

NOVE, Alec. The Soviet Economic System. London: George Allen \& Unwin, 1977. Tables. $\$ 23.25$, cloth. $\$ 10.95$, paper. 
PALIJ, Michael. The Anarchism of Nestor Makhno, 1918-1921: An Aspect of the Ukrainian Revolution. Seattle and London: Univ. of Washington Press, 1976. xiv, 428 pp. Photographs. $\$ 14.50$.

PARMING, Tönu, and Elmar Järvesoo, eds. A Case Study of a Soviet Republic: The Estonian SSR. Foreword by Edward Allworth. Published with the Cooperation of the Estonian Learned Society in America. Boulder, Colo.: Westview Press, 1978. xxvi, 432 pp. $\$ 22.00$.

PASCU, Stefan, gen. ed. Documenta Romaniae Historica, ser. C: Transilvania, vol. 10: (1351-1355). Bucharest: Editura Academiei Republicii Socialiste România, 1977. xliv, 461 pp. Lei 36.

Probleme fundamentale ale istoriei patriei și partidului comunist Român: Prelegeri. Bucharest: Editura Didactică și Pedagogică, 1977. 309 pp. Lei 10.90, paper.

PRPIC, George J. South Slavic Immigration in America. Boston: Twayne Publishers, G. K. Hall, 1978. 302 pp. +8 pp. photographs. $\$ 11.95$.

PUTNAM, George F. Russian Alternatives to Marxism: Christian Socialism and Idealistic Liberalism in Twentieth-Century Russia. Knoxville: Univ. of Tennessee Press, 1977. xii, 233 pp. $\$ 13.50$.

SAUL, Norman E. Sailors in Revolt: The Russian Baltic Fleet in 1917. Lawrence: Regents Press of Kansas, 1978. xiv, 312 pp. +8 pp. plates. $\$ 12.50$.

SCHMEMANN, Alexander, ed. Ultimate Questions: An Anthology of Modern Russian Religious Thought. Crestwood, N.Y.: St. Vladimir's Seminary Press, 1977. viii, 310 pp. Paper.

SCHULZ, Eberhard, ed. Die Ostbeziehungen der éuropäischen Gemeinschaft: Von nationalstaatlicher Politik zu gemeinsamer Verantwortung. Munich and Vienna: R. Oldenbourg Verlag, 1977. 272 pp. DM 46.

SEATON, Albert. The Crimean War: A Russian Chronicle. New York: St. Martin's Press, 1977. 232 pp. +8 pp. plates. Maps. $\$ 12.95$.

SINOR, Denis, ed. Modern Hungary: Readings from The New Hungarian Quarterly. Bloomington and London: Indiana Univ. Press, 1977. xxii, 424 pp. $\$ 17.50$.

SOLOMON, Peter H., Jr. Soviet Criminologists and Criminal Policy: Specialists in Policy-Making. New York: Columbia Univ. Press, 1978. x, 253 pp. $\$ 15.00$.

STERNBERG, Hilary, and Richard Moore, eds. Fodor's Soviet Union 1978. New York: David McKay, 1978. 543 pp. +12 pp. plates. Illus. $\$ 13.95$.

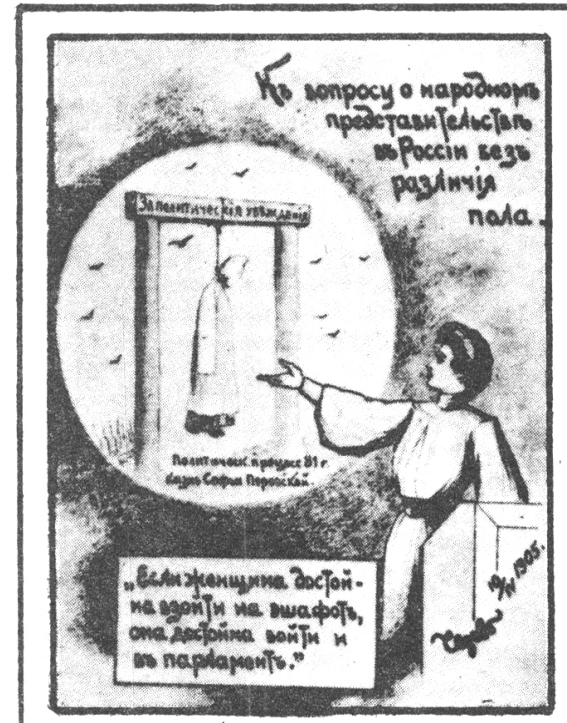

The Women's Liberation

\section{Movement in Russia}

Feminism, Nihilism,

and Bolshevism, 1860-1930

RICHARD STITES

"This is the first narrative history of the Russian women's movement, and it is greatly needed. It provides a whole developing field of study. No one else has Richard Stites' range of knowledge and grasp of sources in this area." - Sheila Fitzpatrick, Columbia University Illus. Cloth, $\$ 37.50$ Limited Paperback Edition, $\$ 12.50$

\section{Dostoevsky and the Novel The Wages of Biography \\ MICHAEL HOLQUIST}

"Here are excellent, useful and detailed readings of specific texts, discussed in the context of the developing form of the novel in the 19th century. . . . Prof. Holquist belongs to that admirable school of scholars who strive to reduce their literary observations and insights to a manageable length and a direct, simple rhetoric." - Doris Grumbach, The New York Times Book Review $\$ 12.50$

Princeton University Press

Princeton, New Jersey 08540 
STOLZ, Benjamin A., ed. Papers in Slavic Philology, 1: In Honor of James Ferrell. Ann Arbor: Dept. of Slavic Langs. \& Lits., Univ. of Michigan, 1977. vi, 326 pp. Paper.

STUPPERICH, Robert, ed., in collaboration with Ostkirchen Institut. Kirche im Osten: Studien zur osteuropäischen Kirchengeschichte und Kirchenkunde, vols. 18, 19, and 20. Göttingen: Vandenhoeck \& Ruprecht, 1975-77. Vol. 18: 1975. 192 pp. DM 28. Vol. 19: 1976. 192 pp. DM 28. Vol. 20: 1977. 195 pp. DM 32.

TECKENBERG, Wolfgang. Die soziale Struktur der sowjetischen Arbeiterklasse im internationalen Vergleich: Auf dem Wege zur industrialisierten Ständegesellschaft? Foreword by Erwin K. Scheuch. Munich and Vienna: R. Oldenbourg Verlag, 1977. 228 pp. Tables. DM 48, paper.

THOMSON, Boris. Lot's Wife and the Venus of Milo: Conflicting Attitudes to the Cultural Heritage in Modern Russia. New York and London: Cambridge Univ. Press, 1978. vi, 171 pp. $\$ 14.95$.

TIHANY, Leslie Charles. The Baranya Dispute 1918-1921: Diplomacy in the Vortex of Ideologies. East European Monographs, 35. Boulder, Colo.: East European Quarterly, 1978. xii, 138 pp. $\$ 11.00$. Dist. by Columbia Univ. Press, New York.

TOWNSEND, Charles E. The Memoirs of Princess Natal'ja Borisovna Dolgorukaja. Columbus, Ohio: Slavica, 1977. viii, 146 pp. \$7.95, paper.

Travaux du Colloque de sociologie juridique Franco-Soviétique (Paris, Octobre 1975). Paris: Editions du Centre National de la Recherche Scientifique, 1977. 275 pp. 75 F., paper.

WARD, Charles A. Next Time You Go to Russia: A Guide to Historical Landmarks and Art Museums with Maps, Illustrations and Descriptive Commentary. Washington, D.C.: Academic Travel Books, 1977. vi, 142 pp. Illus. Maps. Paper.
WARNER, Edward L., III. The Military in Contemporary Soviet Politics: An Institutional Analysis. New York and London: Praeger, 1977. x, 315 pp. Appendix.

YERGIN, Daniel. Shattered Peace: The Origins of the Cold War and the $\mathrm{Na}$ tional Security State. Boston: Houghton Mifflin, 1977. xii, 526 pp. $\$ 15.00$.

ZEMAN, Jarold $\mathrm{K}$. The Hussite Movement and the Reformation in Bohemia, Moravia and Slovakia (1350-1650): A Bibliographical Study Guide (With Particular Reference to Resources in North America). Published under the auspices of the Center for Reformation Research. Ann Arbor: Michigan Slavic Publications, Univ. of Michigan, 1977. xxxviii, 390 pp.

\section{REPRINTS AND NEW EDITIONS}

DMYTRYSHYN, Basil. USSR: A Concise History. 3rd ed. New York: Charles Scribner's Sons, 1978 [1965, 1971]. xxii, 646 pp. Illus. Maps. $\$ 17.50$.

HIPPIUS, Zinaida N. Tret'ja kniga rasskazov: Drittes Buch der Erzählungen. Reprint of St. Petersburg 1902 ed. Intro. by Tamira Pachmuss. Munich: Wilhelm Fink Verlag, 1977. xxvi, 466 pp. DM 58, paper.

HIPPIUS, Zinaida N. Zerkala: Spiegel. Zweites Buch der Erzählungen. Reprint of St. Petersburg 1898 ed. Intro. by Tamira Pachmuss. Munich: Wilhelm Fink Verlag, 1977. xx, 505 pp. DM 58, paper.

OINAS, Felix J., ed. Folklore, Nationalism and Politics. Columbus, Ohio: Slavica, 1978 [1972, 1975]. 189 pp. \$8.95, paper.

STEIGERWALD, Robert. Anti-Communist Myths in Left Disguise. Trans. by Joan Becker. New York: International Publishers, 1977 [Berlin: Akademie-Verlag, 1972, under the title Marxistische Klassenanalyse oder spatburgerliche Mythen]. 109 pp. $\$ 1.75$, paper. 